\title{
Pengaruh Perilaku Belajar, Kecerdasan Emosional dan Kecerdasan Adversitas pada Tingkat Pemahaman Akuntansi
}

\author{
Made Suwi Novita Devi' \\ Fakultas Ekonomi dan Bisnis \\ Universitas Udayana, Indonesia \\ Email: suwinovita@gmail.com
}

\author{
I Ketut Sujana ${ }^{2}$ \\ Fakultas Ekonomi dan Bisnis \\ Universitas Udayana, Indonesia
}

\section{Wayan Pradnyantha Wirasedana ${ }^{3}$ \\ Fakultas Ekonomi dan Bisnis \\ Universitas Udayana, Indonesia}

\begin{abstract}
ABSTRAK
Penelitian ini bertujuan untuk mengetahui pengaruh perilaku belajar, kecerdasan emosional dan kecerdasan a d versitas pada tingkat pemahaman akuntansi. Penelitian dilakukan pada mahasiswa ProgramStudi S1 Akuntansi Reguler Bukitangkata n 2016. Jumlah sampel sebanyak 142 orang menggu na kan teknik purposive sampling. Teknik analisis yang digunakan adalah Analisis Regresi Linear Berganda. Hasil penelitian men emukan bahwa perilaku belajar tidak berpengaruh pada tingkat pemahamanakuntansi.Sedangkan, kecerdasan emosional dan kecerdasan adversitas berpengaruh positif pada tingkat pemahamanakuntansi.
\end{abstract}

Kata Kunci: Tingkat Pemahaman Akuntansi; Perilaku Belaja r; KecerdasanEmosional; Kecerdasan Adversitas.

\section{Effects of Learning Behavior, Emotional Intelligence and Adversity Intelligence on The Levels of Understanding Accounting}

\section{ABSTRACT}

This study aims to determine the effect oflearning behavior, emotional intelligence and adversity intelligence on the levels of understanding accounting. The study was conducted on students of the S1 Accounting Study Program at 2016 Regular Bukit Class. This study uses 142 people for sample, by used a purposive sampling technique. The analysis technique used Multiple Linear Regression Analysis.The results found that learning behavior had no effect on the levels of understanding accounting. Meanwhile, emotional intelligence and adversity intelligence have a positive effect on the levels of understanding accounting.

\footnotetext{
Keywords: Levels of Understanding Accounting; Learning Behavior; Emotional Intelligence; Adversity Intelligence.
}

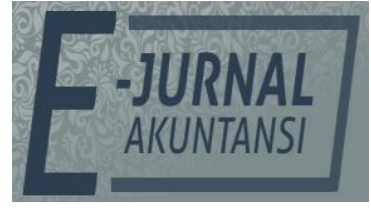

E-JA

e-Jurnal Akuntansi e-ISSN 2302-8556

Vol. 30 No. 4 Denpasar, April 2020

Hal.897-910

Artikel Masuk: 20 Desember 2019

Tanggal Diterima: 3 Maret 2020 


\section{PENDAHULUAN}

Pemahaman akuntansi dapat diartikan sebagai cara mahasiswa akuntansi untuk memahami mata kuliah akuntansi (Dewi et al., 2018). Tingkat pemahaman akuntansi mahasiswa dilihat dari seberapa mengerti seorang mahasiswa terhadap mata kuliah yang telah dipelajari serta dari hasil pencapaian mata kuliah tersebut dapat dilihat dari besaran Indeks Prestasi Kumulatif (IPK) yang diperoleh. Prestasi akademik merupakan bidang fokus yang penting karena merupakan salah satu indikator keberhasilan pendidikan yang dapat mengarah pada akses karir kedepan (Huda \& Mulyana, 2018). Menjadi lulusan akuntansi diharapkan mampu memahami bagaimana siklus akuntansi dan mampu menghasilkan laporan keuangan (Laksmi \& Sujana, 2017). Namun pada praktiknya masih terdapat mahasiswa akuntansi yang telah selesai menempuh mata kuliah akuntansi secara keseluruhan hingga semester enam, namun merasa masih belum memahami akuntansi secara maksimal (salah satunya dalam penyusunan laporan keuangan). Hal ini dapat dilihat berdasarkan data yang didapatkan oleh peneliti berupa nilai mata kuliah mahasiswa akuntansi angkatan 2016 di Fakultas Ekonomi dan Bisnis Universitas Udayana dan hasil wawancara secara langsung kepada responden (mahasiswa). Data yang diperoleh peneliti, disajikan pada Tabel 1.

Tabel 1. IPK Mahasiswa dan Hasil Wawancara

\begin{tabular}{llllll}
\hline \multirow{2}{*}{ IPK } & \multicolumn{4}{l}{ Tingkat Pemahaman Akuntansi } & Total \\
\cline { 2 - 5 } & STP & TP & P & SP & (Orang) \\
\hline $3,31-3,40$ & - & 2 & 3 & - & 5 \\
$3,41-3,50$ & - & - & 3 & - & 3 \\
$3,51-3,60$ & - & 1 & 11 & 3 & 15 \\
$3,61-3,70$ & - & 3 & 16 & 6 & 25 \\
$3,71-3,80$ & - & 5 & 48 & 11 & 64 \\
$3,81-3,90$ & - & - & 32 & 5 & 37 \\
$3,91-4,00$ & - & - & 14 & 2 & 16 \\
TOTAL & 0 & 11 & 127 & 27 & 165 \\
\hline
\end{tabular}

Sumber: Data Penelitian, 2019

Keterangan:

IPK = indeks prestasi kumulatif

STP = sangat tidak paham

$\mathrm{TP}=$ tidak paham

$\mathrm{P} \quad=$ paham

$\mathrm{SP} \quad=$ sangat paham

Total = mahasiswa angkatan 2016 bukit

Tabel 1. terdiri dari indeks prestasi kumulatif yang telah dicapai mahasiswa hingga semester 6 dan hasil wawancara tentang sejauh mana tingkat pemahaman akuntansi yang diperoleh. Data tersebut merupakan gambaran umum mengenai populasi dari penelitian ini yaitu sebanyak 165 orang yang merupakan mahasiswa aktif. Data tersebut menunjukkan rentangan nilai ratarata mata kuliah akuntansi mahasiswa angkatan 2016 yang telah ditempuh hingga semester enam. Dimana nilai yang diperoleh sangat bervarian, begitu pula dengan hasil wawancara langsung yang dilakukan oleh peneliti kepada 
mahasiswa yang bersangkutan tentang sejauh mana pemahaman yang telah diperoleh yang juga bervariasi.

Tabel 1. mencerminkan tingkat pemahaman akuntansi pada mahasiswa yang berbeda-beda meskipun masih dalam satu rentang nilai. Hal ini yang akhirnya menimbulkan paradoks dikalangan mahasiswa. Diasumsikan bahwa mahasiswa yang berada di rentang nilai 3,81 - 4,00 seharusnya digolongkan pada tingkat pemahaman yaitu "sangat paham" dan mahasiswa yang berada di rentang nilai 3,31 - 3,60 seharusnya digolongkan pada tingkat pemahaman yaitu "tidak paham dan paham". Namun pada praktiknya, setelah peneliti melakukan wawancara langsung kepada responden yang bersangkutan, masih terdapat perbedaan antara nilai dengan pernyataan yang diberikan tentang sejauh mana responden paham terhadap mata kuliah akunansi yang telah ditempuh.

Keluhan yang sering muncul terhadap akuntansi adalah pendapat bahwa akuntansi merupakan pelajaran yang sulit, padahal akuntansi bukan hanya bidang yang menggunakan angka-angka dan memfokuskan pada masalah perhitungan semata, akan tetapi akuntansi juga merupakan bidang studi yang menggunakan penalaran yang membutuhkan logika (Pasek, 2015). Secara umum, terdapat dua faktor yang mempengaruhi tingkat pemahaman akuntansi yaitu faktor eksternal dan faktor internal. Faktor internal meliputi faktor fisik dan faktor psikologis, salah satunya yaitu perilaku belajar.

Perilaku belajar mahasiswa saat di perguruan tinggi dapat mencerminkan bagaimana proses mahasiswa tersebut dalam memahami materi. Perilaku belajar mahasiswa berkaitan erat dengan penggunaan waktu untuk belajar serta melakukan kegiatan lainnya. Banyak hal dalam perilaku belajar yang dapat mempengaruhi proses belajar mahasiswa. Berdasarkan wawancara yang dilakukan peneliti kepada beberapa responden, didapatkan bahwa seorang mahasiswa dapat mengikuti perkuliahan tanpa memiliki catatan dan buku pegangan, namun ada juga mahasiswa yang tidak dapat mengikuti perkuliahan tanpa memiliki catatan dan buku pegangan. Mahasiswa dituntut untuk memiliki rasa tanggung jawab dalam menyelesaikan segala tugas secara mandiri, pada kenyataannya masih terdapat mahasiswa yang membutuhkan diskusi untuk menyelesaikan tugasnya (Yulianti, 2017). Fenomena lain yang kerap dijumpai adalah mahasiswa yang hanya bergantung dengan materi yang diberikan oleh dosen dalam perkuliahan tanpa mencari tahu lebih mendalam dengan mandiri. Perilaku belajar tersebut dirasa dapat berdampak pada pemahaman yang dimiliki oleh mahasiswa khususnya jurusan akuntansi.

Faktor internal lainnya yaitu berhubungan dengan kapasitas, salah satunya adalah kecerdasan. Pada dasarnya, manusia diciptakan dengan membawa unsur-unsur kecerdasan yang kapasitasnya berbeda. Awalnya kecerdasan yang diketahui hanyalah sebatas kecerdasan intelektual (IQ), namun seiring berkembanganya ilmu, maka ditemukan unsur-unsur kecerdasan lainnya yang terbentuk menjadi kecerdasan ganda (multiple intelligence). Kecerdasan yang dimiliki mahasiswa sangat mempengaruhi bagaimana suatu materi yang disajikan dapat dipahami (Dewi, 2017).

Salah satu faktor yang dapat mendukung keberhasilan untuk memahami akuntansi adalah mental mahasiswa dalam mengembangkan keperibadiannya (Ariantini et al., 2014). Faktor tersebut sering diistilahkan dengan Kecerdasan 
Emosional atau Emotional Quotient (EQ). EQ juga berperan dalam keberhasilan mahasiswa di tingkat universitas (Huerta et al., 2016). Seseorang yang mampu memahami emosi dari orang lain, dapat bersikap dan mengambil keputusan yang tepat tanpa merugikan kedua belah pihak, serta akan mampu mengendalikan emosinya sehingga menghasilkan optimalisasi pada segala aspek kegiatannya.

Teori kecerdasan ganda (multiple intelligence) menjelaskan faktor yang mempengaruhi kecerdasan salah satunya adalah aktivitas belajar (Gayatri, 2019). Perilaku belajar yang baik akan mengarah pada pemahaman akuntansi menjadi maksimal, sedangkan perilaku belajar yang buruk dapat mengarah pada pemahaman yang kurang maksimal. Paham tidaknya mahasiswa terhadap mata kuliah akuntansi merupakan salah satu cerminan dari keberhasilan mahasiswa dalam belajar. Pengukuran tingkat keberhasilan mahasiswa dalam belajar juga dapat dilihat dari jenjang prestasi akademik yang telah dicapai (Gayatri, 2019).

Penelitian yang dilakukan oleh Agustin \& Sujana (2018), Suprianto (2016), Gayatri, (2019), dan Kresnandra (2019) menyimpulakan bahwa perilaku belajar berpengaruh positif dan signifikan pada tingkat pemahaman akuntansi. Namun, hasil penelitian tersebut berbanding dengan penelitian yang dilakukan oleh Widyawati et al. (2014) dan Parauba (2014) menyimpulkan bahwa perilaku belajar berpengaruh negatif terhadap tingkat pemahaman akuntansi. Serta penelitian yang dilakukan Maryati (2017) dan Susanti (2017) menyatakan bahwa perilaku belajar tidak berpengaruh terhadap tingkat pemahaman akuntansi.

$\mathrm{H}_{1}$ : Perilaku belajar berpengaruh positif pada tingkat pemahaman akuntansi.

Kecerdasan emosional memainkan peran dalam keberhasilan profesi akuntansi (Verma, 2017). Satu studi yang mencakup kecerdasan emosional dan perilaku sosial menggaris bawahi bahwa mahasiswa dengan keseimbangan emosional yang baik, memiliki kinerja yang lebih baik daripada mereka yang frustrasi yang menghasilkan perilaku yang lebih peduli dan terlibat dalam pendidikan (Ahmed et al., 2019). Hasil penelitian yang dilakukan Rusmiani (2017) dan Dewi (2016) menunjukkan bahwa Kecerdasan Emosional berpengaruh signifikan terhadap tingkat pemahaman akuntansi di kalangan mahasiswa. Penelitian yang dilakuan oleh Sari (2019) yang menunjukkan bahwa kecerdasan emosional berpengaruh positif signifikan pada pemahaman akuntansi. Namun, hasil-hasil penelitian tersebut dibantah oleh penelitian Laksmi \& Sujana (2017) dan Widyawati et al. (2014) yang menyatakan bahwa kecerdasan emosional tidak mempengaruhi tingkat pemahaman akuntansi. Sejalan dengan penelitian yang dilakukan Maiquez et al. (2015) bahwa kecerdasan emosional tidak dapat memprediksi pencapaian akademik.

$\mathrm{H}_{2}$ : Kecerdasan emosional berpengaruh positif pada tingkat pemahaman akuntansi.

Rasa keingintahuan dan tidak takut dengan kegagalan akan mendorong seseorang untuk mengeksplorasi ilmunya lebih jauh lagi, dan memungkinkan seseorang untuk mencapai prestasi yang maksimal. Penelitian mengenai hubungan antara pengaruh kecerdasan adversitas pada tingkat pemahaman akuntansi masih jarang dilakukan, namun dari beberapa penelitian terdahulu terdapat inkonsistensi yang masih layak untuk dibuktikan kebenarannya. 
Penelitian Husnurrosyidah (2015), (Libraeni, 2018), dan Capuras et al. (2016) menunjukkan bahwa kecerdasan adversitas berpengaruh terhadap tingkat pemahaman akuntansi. Namun penelitian tersebut dibantah oleh penelitian Villagonzalo (2016) yang berpendapat bahwa kecerdasan adversitas tidak berpengaruh terhadap pencapain kinerja akademik mahasiswa. Berdasarkan penjelasan pada penelitian ini, maka peneliti tertarik untuk merumuskan hipotesis berikut:

$\mathrm{H}_{3}$ : Kecerdasan Adversitas berpengaruh positif pada tingkat pemahaman akuntansi.

\section{METODE PENELITIAN}

Penelitian ini dilakukan di Program Program Studi Akuntansi Angkatan 2016 di Fakultas Ekonomi dan Bisnis, Universitas Udayana. Obyek pada penelitian ini adalah tingkat pemahaman akuntansi dari mahasiswa akuntansi angkatan 2016 di FEB Unud. Diduga tingkat pemahaman akuntansi mahasiswa dipengaruhi oleh perilaku belajar, kecerdasan emosional dan kecerdasan adversitas. Populasi dalam penelitian ini adalah mahasiswa Program Studi S1 Akuntansi Reguler Bukit angkatan 2016 sebanyak 179 mahasiswa. Alasan peneliti menggunakan populasi tersebut, karena mahasiswa angkatan 2016 dianggap telah berada diakhir masa perkuliahan. Selain itu, mahasiswa Program S1 Akuntansi Bukit angkatan 2016 tidak menyelenggarakan Kerja Profesi Mahasiswa (KPM) maupun Praktik Kerja Lapangan (PKL) sehingga dianggap belum pernah mempraktikan ilmunya di dunia kerja. Sampel penelitian ini sebanyak 142 mahasiswa. Teknik penentuan sampel dalam penelitian ini menggunakan teknik purposive sampling. Purposive sampling adalah metode pengambilan sampel berdasarkan kriteriakriteria tertentu yang dianggap dapat mewakili objek yang akan diteliti (relevan) sesuai dengan tujuan penelitian. Analisis regresi linear berganda (multiple linear regression) digunakan untuk mengukur besarnya pengaruh variabel bebas terhadap variabel terikat dan memprediksi variabel terikat dengan menggunakan variabel bebas. Analisis regresi linear berganda digunakan untuk menguji hipotesis yang ada yaitu untuk melihat pengaruh perilaku belajar, kecerdasan emosional dan kecerdasan adversitas pada tingkat pemahaman akuntansi. Analisis regresi linier berganda ini diukur dengan bantuan program software SPSS 21 for Windows. Model persamaan analisis regresi linear ber gand a ditunjukkan oleh persamaan berikut:

$Y=\alpha+\beta_{1} X_{1+} \beta_{1} X_{2}+\beta_{1} X_{3}+e$

Keterangan:

$\mathrm{Y}=$ Tingkat Pemahaman Akuntansi

$\mathrm{a} \quad=$ Konstanta

$\beta_{1}-\beta_{3}=$ Koefisien regresi untuk masing-masing variabel independen

$\mathrm{X}_{1} \quad=$ Perilaku Belajar

$\mathrm{X}_{2}=$ Kecerdasan Emosional

$\mathrm{X}_{3}=$ Kecerdasan Adversitas

e $\quad=$ Standar Error 


\section{HASIL DAN PEMBAHASAN}

Statistik deskriptif digunakan untuk memberikan gambaran dari suatu data yang dilihat dari jumlah sampel, nilai minimum, nilai maksimum, nilai rata-rata (mean), dan devisiasi standar (Std. devitiation) dari masing-masing variabel dalam penelitian tanpa adanya maksud untuk menarik kesimpulan. Hasil dari statistik deskriptif dapat dilihat pada Tabel 2.

Tabel 2. Hasil Statistik Deskriptif

\begin{tabular}{llllll}
\hline Variabel & $\mathrm{N}$ & Minimum & Maximum & Mean & $\begin{array}{l}\text { Std. } \\
\text { Devitiation }\end{array}$ \\
\hline Perilaku belajar & 142 & 20 & 32 & 22,99 & 2,260 \\
Kecerdasanemosional & 142 & 21 & 37 & 29,51 & 3,268 \\
$\begin{array}{l}\text { Kecerdasanadversitas } \\
\text { Tingkat pemahaman }\end{array}$ & 142 & 20 & 32 & 24,30 & 2,021 \\
akuntansi & 32 & 59 & 49,79 & 3,622 \\
\hline
\end{tabular}

Sumber: Data Penelitian, 2019

Variabel perilaku belajar $\left(\mathrm{X}_{1}\right)$ memiliki nilai rata-rata (mean) sebesar 22,99.

Nilai rata-rata 22,99 ini artinya ada kecenderungan nilai rata-rata mendekati nilai minimum. Hal ini berarti bahwa berdasarkan jawaban atas pernyataan yang terdapat pada kuesioner variabel perilaku belajar, mengindikasikan bahwa perilaku belajar yang diterapkan mahasiswa cenderung rendah. Nilai standar deviasi perilaku belajar sebesar 2,260. Nilai ini lebih rendah dibandingkan nilai rata-rata. Hal ini menunjukkan bahwa sebaran data berupa jawaban respo nden pada butir-butir pernyataan perilaku belajar dapat dinyatakan sudah merata atau rentang data satu dengan yang lainnya tidak tergolong tinggi.

Variabel kecerdasan emosional $\left(X_{2}\right)$ memiliki nilai rata-rata (mean) sebesar 29,51. Nilai rata-rata 29,51 ini artinya ada kecenderungan nilai rata-rata mendekati nilai maksimum. Hal ini berarti bahwa berdasarkan jawaban atas pernyataan yang terdapat pada kuesioner variabel kecerdasan emosional, mengindikasikan bahwa kecerdasan emosional yang dimiliki mahasiswa cenderung tinggi. Nilai standar deviasi kecerdasan emosional sebesar 3,268. Nilai ini lebih rendah dibandingkan nilai rata-rata. Hal ini menunjukkan bahwa sebaran data berupa jawaban responden pada butir-butir pernyataan kecerdasan emosional dapat dinyatakan sudah merata atau rentang data satu dengan yang lainnya tidak tergolong tinggi.

Variabel kecerdasan adversitas $\left(\mathrm{X}_{3}\right)$ memiliki nilai rata-rata (mean) sebesar 24,30. Nilai rata-rata 24,30 ini artinya ada kecenderungan nilai rata-rata mendekati nilai minimum. Hal ini berarti bahwa berdasarkan jawaban atas pernyataan yang terdapat pada kuesioner variabel kecerdasan adversitas, mengindikasikan bahwa kecerdasan adversitas yang dimiliki mahasiswa cenderung rendah. Nilai standar deviasi kecerdasan adversitas sebesar 2,021. Nilai ini lebih rendah dibandingkan nilai rata-rata. Hal ini menunjukkan bahwa sebaran data berupa jawaban responden pada butir-butir pernyataan kecerdasan adversitas dapat dinyatakan sudah merata atau rentang data satu dengan yang lainnya tidak tergolong tinggi.

Variabel tingkat pemahaman akuntansi (Y) memiliki nilai rata-rata (mean) sebesar 49,79. Nilai rata-rata 49,79 ini artinya ada kecenderungan nilai rata-rata 
mendekati nilai maksimum. Hal ini berarti bahwa berdasarkan jawaban atas pertanyaan yang terdapat pada kuesioner variabel tingkat pemahaman akuntansi, mengindikasikan bahwa tingkat pemahaman akuntansi yang dimiliki mahasiswa cenderung tinggi. Nilai standar deviasi tingkat pemahaman akuntansi sebesar 3,622. Nilai ini lebih rendah dibandingkan nilai rata-rata. Hal ini menunjukkan bahwa sebaran data berupa jawaban responden pada butirbutir pertanyaan tingkat pemahaman akuntansi dapat dinyatakan sudah merata atau rentang data satu dengan yang lainnya tidak tergolong tinggi.

Analisis regresi linear berganda digunakan untuk menguji hipotesis yang ada yaitu untuk melihat pengaruh perilaku belajar $\left(X_{1}\right)$, kecerdasan emosional $\left(X_{2}\right)$ dan kecerdasan adversitas $\left(X_{3}\right)$ pada tingkat pemahaman akuntansi $(Y)$. Analisis regresi linier berganda ini diukur dengan bantuan program software SPSS 21 for Windows. Hasil analisis regresi linear berganda pada penelitian ini disajikan dalam Tabel 3.

Tabel 3. Hasil Analisis Regresi Linear Berganda

\begin{tabular}{|c|c|c|c|c|c|}
\hline \multirow[t]{2}{*}{ Model } & \multicolumn{2}{|c|}{$\begin{array}{l}\text { Unstandardized } \\
\text { coefficients }\end{array}$} & \multirow{2}{*}{$\begin{array}{l}\text { Standardized } \\
\text { coefficients } \\
\text { Beta }\end{array}$} & \multirow[t]{2}{*}{$t$} & \multirow[t]{2}{*}{ Sig. } \\
\hline & B & Std. Error & & & \\
\hline 1 (Constant) & 26,736 & 3,525 & & 7,584 & 0,000 \\
\hline Perilaku belajar & 0,238 & 0,137 & 0,148 & 1,734 & 0,085 \\
\hline Kecerdasan emosional & 0,309 & 0,117 & 0,277 & 2,628 & 0,010 \\
\hline Kecerdasanadversitas & 0,349 & 0,175 & 0,195 & 1,990 & 0,049 \\
\hline \multicolumn{6}{|c|}{ Variabel Dependen:TingkatPemahaman Akuntansi } \\
\hline
\end{tabular}

Sumber: Data Penelitian, 2019

Hasil analisis regresi linear berganda pada Tabel 3. menunjukkan nilai koefisien regresi dari variabel bebas (perilaku belajar, kecerdasan emosional dan kecerdasan adversitas) dan nilai konstanta variable terikat (tingkat pemaha man akuntansi), maka dapat diperoleh persamaan regresi linear berganda sebagai berikut:

Keterangan:

$$
Y=26,736+0,238 X_{1}+0,309 X_{2}+0,349 X_{3}+e
$$

$$
\begin{array}{ll}
\mathrm{Y} & =\text { Tingkat Pemahaman Akuntansi } \\
\mathrm{a} & =\text { Konstanta } \\
\beta_{1}-\beta_{3} & =\text { Koefisien regresi untuk masing-masing variabel independen } \\
\mathrm{X}_{1} & =\text { Perilaku Belajar } \\
\mathrm{X}_{2} & =\text { Kecerdasan Emosional } \\
\mathrm{X}_{3} & =\text { Kecerdasan Adversitas } \\
\mathrm{e} & =\text { Standar Error }
\end{array}
$$

Hipotesis pertama $\left(\mathrm{H}_{1}\right)$ yang diajukan menyatakan perilaku belajar berpengaruh positif pada tingkat pemahaman akuntansi. Hasil penelitian menunjukkan bahwa perilaku belajar memiliki nilai koefisien regresi sebesar 0,238 dengan nilai signifikansi sebesar 0,085 > a $(0,05)$ yang berarti bahwa variabel perilaku belajar tidak memiliki pengaruh pada tingkat pemahaman akuntansi. Hasil tersebut membuktikan bahwa $\mathrm{H}_{1}$ yang menyatakan "perilaku belajar berpengaruh positif pada tingkat pemahaman akuntansi", tidak terbukti kebenarannya atau $\mathrm{H}_{1}$ pada penelitian ini ditolak. Dengan kata lain, baik atau tidaknya perilaku belajar yang dilakukan oleh mahasiswa saat menempuh mata 
kuliah akuntansi, tidak memengaruhi tingkat pemahaman akuntansi yang dimiliki oleh mahasiswa tersebut. Berdasarkan teori kecerdasan ganda (multiple intelligence), faktor yang memengaruhi kecerdasan salah satunya adalah aktivitas belajar (Gayatri, 2019). Dalam hal ini, aktivitas belajar tidak hanya dilihat dari perilaku belajar yang merupakan faktor internal tetapi mungkin juga dari faktor eksternal seperti budaya belajar yang ada disekitar.

Hasil penelitian ini mendukung penelitian yang dilakukan oleh Susanti (2017) dan Pratsetyaningsih (2018) yang menyatakan bahwa perilaku belajar tidak berpengaruh pada pemahaman akuntansi. Hal ini dapat disebabkan karena setiap mahasiswa memiliki cara masing-masing dalm proses belajar guna mencapai tujuan yang diharapkan. Selain itu, hasil penelitian ini juga mendukung penelitian yang dilakuka oleh Maryati (2017) menyatakan bahwa perilaku belajar tidak berpengaruh pada tingkat pemahaman akuntansi, hal ini bisa saja disebabkan oleh faktor lain seperti kebiasaan belajar yang kurang baik, yaitu waktu belajar yang tidak teratur dan kebiasaan membaca yang buruk, adanya tekanan mental dan bahan pelajaran yang tidak sesuai dengan standar dan harapan.

Hipotesis kedua $\left(\mathrm{H}_{2}\right)$ yang diajukan menyatakan kecerdasan emosional berpengaruh positif pada tingkat pemahaman akuntansi. Hasil penelitian menunjukkan bahwa kecerdasan emosional memiliki nilai koefisien regresi sebesar 0,309 dengan nilai signifikansi sebesar $0,010<a(0,05)$ yang berarti bahwa variabel kecerdasan emosional memiliki pengaruh positif pada tingkat pemahaman akuntansi. Hasil tersebut membuktikan bahwa $\mathrm{H}_{2}$ yang menyatakan "kecerdasan emosional berpengaruh positif pada tingkat pemahaman akuntansi", terbukti kebenarannya atau $\mathrm{H}_{2}$ pada penelitian ini diterima. Hasil ini menunjukkan semakin tinggi kecerdasan emosional yang dimiliki mahasiswa, maka akan semakin tinggi pula tingkat pemahaman akuntansi mahasiswa tersebut. Dimana kecerdasan emosional mampu mengarahkan seseorang untuk mengakui dan menghargai perasaan diri sendiri dan orang lain serta mengolah emosi pribadi dengan baik Wardana (2016). Hasil penelitian ini mendukung adanya teori kecerdasan ganda (multiple intelligence) yang menjelaskan bahwa dalam diri manusia terdapat motif-motif yang mendorong manusia untuk berinteraksi dengan dunia luar interaksi yang dilakukan dapat menimbulkan minat yang mana dapat mendorong seseorang untuk berbuat lebih giat dan baik (Gayatri, 2019).

Hasil penelitian ini didukung dengan adanya penelitian yang dilakukan oleh Dewi (2016) menunjukkan bahwa kecerdasan emosional berpengaruh signifikan terhadap tingkat pemahaman akuntansi di kalangan mahasiswa. Hal ini dikarenakan seseorang dengan kecerdasan emosional yang baik memiliki kemungkinan besar untuk berprestasi selain itu, penelitian ini juga mend ukung penelitian yang dilakukan oleh Sari (2019) yang menyatakan bahwa kecerd asan emosional berpengaruh positif pada tingkat pemahaman akuntansi. Hal ini dapat disebabkan karena mahasiswa dengan keseimbangan emosional yang baik, dianggap memiliki kinerja yang lebih baik daripada mereka yang mengalami tekanan (frustasi), sehingga dapat menghasilkan perilaku yang lebih peduli dan terlibat dalam pendidikannya. 
Hipotesis ketiga $\left(\mathrm{H}_{3}\right)$ yang diajukan menyatakan kecerdasan adversitas berpengaruh positif pada tingkat pemahaman akuntansi. Hasil penelitian menunjukkan bahwa kecerdasan adversitas memiliki nilai koefisien regresi sebesar 0,349 dengan nilai signifikansi sebesar $0,049<$ a $(0,05)$ yang berarti bahwa variabel kecerdasan adversitas memiliki pengaruh positif pada tingkat pemahaman akuntansi. Hasil tersebut membuktikan bahwa $\mathrm{H}_{3}$ yang menyatakan "kecerdasan adversitas berpengaruh positif pada tingkat pemahaman akuntansi", terbukti kebenarannya atau $\mathrm{H}_{3}$ pada penelitian ini diterima. Hasil ini menunjukkan semakin tinggi kecerdasan adversitas yang dimiliki mahasiswa, maka akan semakin tinggi pula tingkat pemahaman akuntansi mahasiswa tersebut.

Hasil penelitian ini didukung dengan penelitian yang dilakukan oleh Husnurrosyidah (2015) dan Libraeni (2018) menunjukkan bahwa kecerdasan adversitas berpengaruh pada tingkat pemahaman akuntansi. Hal ini dikarenakan respon seseorang terhadap kesulitan memengaruhi semua segi efektivitas, kinerja, dan kesuksesan. Rasa keingintahuan dan tidak takut dengan kegagalan akan mendorong seseorang untuk mengeksplorasi ilmunya lebih jauh lagi, dan memungkinkan seseorang untuk mencapai prestasi yang maksimal. Hal ini otomatis akan memengaruhi bagaimana kecerdasan adversitas mampu mendorong keinginan mahasiswa agar tidak takut mengalami kegagalan ataupun masalah untuk memahami akuntansi sehingga akan meningkatkan tingkat pemahaman terhadap akuntansi. Hasil koefisien determinasi yang ditunjukkan pada tabel dibawah ini akan menunjukkan bagaimana persentase variansi tigkat pemahaman akuntansi dipengaruhi oleh perilaku belajar, kecerdasan emosional dan kecerdasan adversitas.

Tabel 4. Hasil Koefisien Determinasi $\left(\mathbf{R}^{2}\right)$

\begin{tabular}{lllll}
\hline Model & $\mathrm{R}$ & $\mathrm{R}$ Square & Adjusted R Square & $\begin{array}{l}\text { Std. Error of the } \\
\text { Estimate }\end{array}$ \\
\hline 1 & 0,525 & 0,275 & 0,260 & 3,116 \\
\hline
\end{tabular}

Sumber: Data Penelitian, 2019

Hasil uji koefisien determinasi dengan Adjusted R2 yang disajikkan, menunjukkan nilai dari Adjusted $\mathrm{R}^{2}$ adalah sebesar 0,260 atau 26 persen, dimana memiliki arti bahwa 26 persen variansi tingkat pemahaman akuntansi dipengaruhi oleh variansi perilaku belajar, kecerdasan emosional, dan kecerdasan adversitas, sedangkan sisanya yang sebesar 74 persen dipengaruhi oleh variabel-variabel lain yang tidak dijelaskan dalam penelitian ini.

Tabel 5. Hasil Uji Kelayakan Model (Uji F)

\begin{tabular}{|c|c|c|c|c|c|}
\hline Model & Sum of Square & $\frac{\mathrm{df}}{\mathrm{df}}$ & Mean Square & $\bar{F}$ & Sig. \\
\hline $\begin{array}{ll}1 & \text { Regression }\end{array}$ & 509,430 & 3 & 169,810 & 17,485 & 0,000 \\
\hline Residual & 1340,232 & 138 & 9,712 & & \\
\hline Total & 1849,662 & 141 & & & \\
\hline
\end{tabular}

Sumber:Data Penelitian, 2019

Hasil uji kelayakan model (Uji F) yang disajikan menunjukkan bahwa signifikansi pada Uji F nilainya lebih kecil dari 0,05 (5 persen), sehingga dapat disimpulkan bahwa model regresi yang dibuat layak digunakan untuk menjelaskan pengaruh perilaku belajar, kecerdasan emosional, dan kecerdasan adversitas pada tingkat pemahaman akuntansi. 


\section{SIMPULAN}

Penelitian ini menjelaskan pengaruh perilaku belajar, kecerdasan emosional, dan kecerdasan adversitas pada tingkat pemahaman akuntansi. Selain itu, hasil pengujian dapat memberikan kontribusi bagi pengembangan ilmu pengetahuan khususnya pada akuntansi keperilakuan, hal ini ditujukan karena akuntansi keperilakuan merupakan ilmu akuntansi yang berfokus tentang efek dari perilaku manusia sehingga dapat memengaruhi data-data akuntansi dan juga pengambilan keputusan. Dengan adanya hasil penelitian pada akuntansi keperilakuan diharapkan dapat memberikan gambaran mengenai faktor yang dapat memengaruhi tingkat pemahaman akuntansi, yang nantinya akan berdampak pada perilaku akuntan yang dihasilkan nantinya. Implikasi praktis dalam penelitian ini adalah hasil analisis pengaruh perilaku belajar, kecerdasan emosional, dan kecerdasan adversitas pada tingkat pemahaman akuntansi diharapkan dapat memberi masukkan kepada mahasiswa akuntansi dalam menjalani proses perkuliahan di perguruan tinggi. Penelitian ini diharapkan dapat memberikan masukkan kepada instansi perguran tinggi guna meningkatkan sistem pembelajaran yang diterapkan agar tidak hanya berfokus pada materi perkuliahan melainkan berfokus pula pada kemampuan atau kapasitas peserta didiknya secara personal saat proses perkuliahan.

\section{REFERENSI}

Agustin, I. A. C., \& Sujana, I. K. (2018). Pengaruh Kecerdasan Emosional, Kecerdasan Spiritual, dan Perilaku Belajar pada Tingkat Pemahaman Akuntansi. E-Journal Akuntansi Universitas Udayana, 25(2), 988-1014. https://doi.org/doi.org/10.24843/EJA.2018.v25.i02.p07

Ahmed, Z., Asim, M., \& Pellitteri, J. (2019). The International Journal of Emotional intelligence predicts academic achievement in Pakistani management students. The International Journal of Management Education, 17(2), 286-293. https://doi.org/10.1016/j.ijme.2019.04.003

Akhtar, M. W., Shabir, A., Safdar, M. S., \& Akhtar, M. S. (2017). Impact of Emotional Intelligence on Turnover Intentions: The Role of Organizational Commitment and Perceive Organizational Support. Journal of Accounting \& Marketing, 6(4), 1-7. https://doi.org/10.4172/2168-9601.1000259

Ariantini, K. N., Sujana, E., \& Herawati, N. T. (2014). Pengaruh Emosional dan Minat Membaca terhadap Tingkat Pemahaman Akuntansi dengan Kepercayaan Diri sebagai Variabel Moderasi (Studi Empiris pada Mahasiswa Jurusan Akuntansi Universitas di Bali). E-Journal S1 Akuntansi Universitas Pendidikan Ganesha, 2(1), 52-62.

Artana, M. B., Herawati, N. T., \& Atmadja, A. W. T. (2014). Pengaruh Kecerdasan Intelektual (IQ), Kecerdasan Emosional (EQ), Kecerdasan Spiritual (SQ), dan Perliaku Belajar terhadap Pemahaman Akuntansi. E-Journal S1 Akuntansi Universitas Pendidikan Ganesha, 2(1), 1-11. 
Capuras, S. B., Engada, M. V. R., Inoferio, H. J. T., \& Querubin, I. E. M. (2016). Adversity Quotient and Perceived Academic Stress as Predictors of The Academic Performance of CDU-CRS Internship Candidates. Thesis. Cebu Doctor's University.

Cetin, B. (2015). Academic Motivation And Self-Regulated Learning In Predicting Academic Achievement In College. Journal of International Education Research (JIER), 11(2), 95-106.

Daloos, M. J. O. (2015). Emotional Intelligence And Adversity Quotient Of Selected Helping Professionals. Thesis. Far Eastern University, Manila.

Dewi, E. T. P., Wafirotin, K. Z., \& Hartono, A. (2018). Pengaruh Kecerdasan Emosional Terhadap Tingkat Pemahaman Akuntansi Dengan Kepercayaan Diri Sebagai Variabel Moderating. Penerbitan Artikel Mahasiswa Universitas Muhammadiyah Ponorogo, 34-41. Retrieved from https://www.researchgate. net

Dewi, N. N. S. R. T., \& Yogantara, K. K. (2017). Pengaruh Kecerdasan Emosional Terhadap Tingkat Pemahaman Akuntansi Dengan Perilaku Belajar Sebagai Pemoderasi. Ekuitas-Jurnal Pendidikan Ekonomi, 5(2), 41-48.

Dewi, N. P. R. A., \& Wirama, D. G. (2016). Kepercayaan Diri sebagai Pemoderasi Pengaruh Kecerdasan Emosional dan Perilaku Belajar pada Tingkat Pemahaman Akuntansi. E-Journal Akuntansi Universitas Udayana, 16(1), 615-644. https://doi.org/ISSN: 2302-8556

Fauziah, N. (2014). Empati, Persahabatan, dan Kecerdasan Adversitas pada Mahasiswa yang Sedang Skripsi. Jurnal Psikologi Undip, 13(1), 78-92

Febriyani, F., \& Priantinah, D. (2017). Pengaruh Kecerdasan Intelektual, Kecerdasan Emosional, Kecerdasan Spiritual Dan Perilaku Belajar Terhadap Tingkat Pemahaman Akuntansi. Jurnal Profita, 17(1), 1-24.

Gayatri, N. P. L., \& Wirawati, N. G. P. (2019). Pengaruh Kecerdasan Intelektual, Kecerdasan Emosional, Kecerdasan Spiritual, dan Perilaku Belajar Terhadap Pemahaman Akuntansi. E-Journal Akuntansi Universitas Udayana, 28(2), 1377-1404. https://doi.org/doi.org/10.24843/EJA.2019.v28.i02.p22

Ghozali, H. I. (2016). Aplikasi Analisis Multivariate dengan Program IBM SPSS 23 (Edisi Kedelapan). Semarang: Badan Penerbit Universitas Diponegoro.

Goleman, D. (1996). Emotional Intelligence: Why It Can Matter More Than IQ. https://doi.org/10.1007/s42243-018-0133-0

Goleman, D. (2016). Emotional Intelligence: Why It Can Matter More Than IQ (A. T. K. Widodo, Ed.). Jakarta: PT Gramedia Pustaka Utama.

Huda, T. N., \& Mulyana, A. (2018). Pengaruh Adversity Quotient terhadap Prestasi Akademik Mahasiswa Angkatan 2013 Fakultas Psikologi UIN SGD Bandung. Psympathic: Jurnal Ilmiah Psikologi, 4(1), 115-132. https://doi.org/10. 15575/psy.v4i1.1336

Huerta, M., Goodson, P., Beigi, M., \& Chlup, D. (2016). ). Graduated Students as Academic Writers: Writing Axiety, Self-Efficacy and Emotional Intelligence. Higher Education Research and Development, 36(4), 716-729. https:// doi.org/10.1080/07294360.2016.1238881

Husnurrosyidah, \& Rahmawaty, A. (2015). Pengaruh Kecerdasan Emosional dan Kecerdasan Spiritual terhadap Pemahaman Akuntansi Syariah dan 
Kecerdasan Adversitas sebagai Variabel Mediasi. Ekonomi Syariah, 3(2), 199-220.

Kresnandra, A. A. N. A. (2019). Pengaruh Perilaku Belajar terhadap Tingkat Pemahaman Akuntansi dengan Kecerdasan Emosional sebagai Variabel Pemoderasi. E-Journal Akuntansi Universitas Udayana, 28(3), 2065-2075. https://doi.org/doi.org/10.24843/EJA.2019.v28.i03.p27

Kumar, R. (2016). The Relationship of Personal Characteristics and Job Satisfaction to Adversity Quotient of Police Officers in Shimla District of Himachal Pradesh. International Journal of Economics $\mathcal{E}$ Management Sciences, 5(3), 1-8. https://doi.org/10.4172/2162-6359.1000331

Laksmi, R. A., \& Sujana, I. K. (2017). Pengaruh Kecerdasan Intelektual, Kecerdasan Emosional dan Kecerdasan Spiritual terhadap Pemahaman Akuntansi. E-Journal Akuntansi Universitas Udayana, 21(2), 1373-1399. https://doi.org/doi.org/10.24843/EJA.2017.v21.i02.p19

Libraeni, L. G. B., \& Ketut, Y. (2018). The Effect of Intelligence Quotient on the Level of Understanding of Accounting with Spiritual Quotient and Adversity Quotient as A Moderating Variables. IJSBAR (International Journal of Sciences Basic and Applied Research), 41(1), 148-157. https://doi.org/ISSN: 2307-4531

Maiquez, R., Precolo, A. C., Sausa, L., \& Talatagod, K. (2015). Predictive Ability of Emotional Intelligence and Adversity Quotient on Academic Performance of USC College Students (University of San Carlos). Thesis. University of San Carlos https://doi.org/10.1192/bjp.111.479.1009-a

Maryati, S. (2017). Faktor-Faktor Yang Mempengaruhi Tingkat Pemahaman Akuntansi (Studi Empiris pada Mahasiswa Akuntansi IBI Darmajaya Lampung). GEMA, 9(1), 45-53. https://doi.org/ISSN: 2086-9592

Parauba, I. (2014). Pengaruh Kecerdasan Intelektual, Kecerdasan Emosional, Kecerdasan Spiritual, Dan Perilaku Belajar Terhadap Pemahaman Akuntansi Mahasiswa Fakultas Ekonomi Dan Bisnis. Jurnal Riset Akuntansi Going Concern, 9(2), 53-67. https://doi.org/10.5209/rev_SJOP.2012.v15.n1.37288

Pasek, N. S., Dwirandra, A. A. N. B., \& Putri, I. G. A. M. A. D. (2015). Pengaruh Kecerdasan Intelektual pada Pemahaman Akuntansi dengan Kecerdasan Emosional dan Kecerdasan Spiritual sebagai Variabel Moderasi. E-Jurnal Ekonomi Dan Bisnis Universitas Udayana, 4(10), 703-714. https:/ /doi.org/ ISSN : 2337-3067

Pratsetyaningsih, E. (2018). Analisis Faktor-Faktor Yang Mempengaruhi Tingkat Pemahaman Akuntansi (Studi Kasus Pada Mahasiswa Semester Akhir Angkatan 2014 Jurusan Akuntansi Fakultas Ekonomi dan Bisnis Universitas Muhammadiyah Surakarta). Skripsi. Universitas Muhammadiyah Surakarta.

Rimbano, D., \& Putri, M. S. E. (2016). Pengaruh Kecerdasan Emosional, Kecerdasan Spiritual, dan Perilaku Belajar pada Tingkat Pemahaman Akuntansi. Jurnal Ilmiah Orasi Bisnis, 15(1), 11-32. https://doi.org/10. 24843/eja.2018.v25.i02.p07 
Rusmiani, N. K. A., \& Widanaputra, A. A. G. . (2017). Pengaruh Kecerdasan Emosional, Kecerdasan Intelektual Dan Perilaku Belajar Pada Tingkat Pemahaman Akuntansi. E-Journal Akuntansi Universitas Udayana, 20(2), 959-985. https://doi.org/ISSN: 2302-8556

Salehi, M., Zadeh, M. A., Ghaderi, A., \& Tabasi, A. Z. (2016). A Study of the Effect of Education and Academic Environment on Emotional Intelligence on Accounting Students in Iran. International Education Studies, 9(1), 182-188. https://doi.org/10.5539/ies.v9n1p182

Sari, M. S. M. P., \& Wirama, D. G. (2019). Pengaruh Komponen Kecerdasan Emosional pada Pemahaman Akuntansi. E-Journal Akuntansi Universitas Udayana, 28(1), 465-490. https://doi.org/ISSN: 2302-8556

Soysub, A., \& Jarinto, K. (2018). The Effects of Multiple Intelligent (IQ, EQ and $\mathrm{AQ})$ on Employee Performance: A Case of ABC Automotive Co. Ltd. RMUTT Global Business Accounting and Finance Review (GBAFR), 2(1), 112.

Sugiyono. (2017). Metode Penelitian dan Bisnis. Bandung: Alfabeta.

Sujana, I. K., Sadha, I. M., \& Pratiwi, N. P. T. W. (2019). The Effect of Intellectual Intelligence , Emotional Intelligence , Spiritual Intelligence and Adversity Intelligence on Profession Performance in Taxation Field with Locus of Control as Moderating Variable. International Journal of Sciences: Basic and Applied Research (IJSBAR), 45(2), 53-63.

Suprianto, E., \& Harryoga, S. (2016). Faktor-Faktor Penentu Tingkat Pemahaman Akuntansi. Jurnal Ekonomi Dan Bisnis, 18(3), 75. https://doi.org/10. 24914/jeb.v18i3.281

Susanti, S., Rispantyo, \& Kristianto, D. (2017). Pengaruh Minat Belajar, Perilaku Belajar, Kecerdasan Intelektual, dan Kecerdasan Emosional Terhadap Tingkat Pemahaman Akuntansi. Jurnal Akuntansi Dan Sistem Teknologi Informasi, 13, 127-134.

Susanti, S., Rispayanto, \& Kristianto, D. (2017). Pengaruh Minat Belajar, Perilaku Belajar, Kecerdasan Intelektual Dan Kecerdasan Emosional Terhadap Tingkat Pemahaman Akuntansi. Jurnal Akuntansi Dan Sistem Teknologi Informasi, 13, 127-134.

Tropman, J., \& Gardner, H. (1985). Frames of the Mind: The Theory of Multiple Intelligence. Journal of Policy Analysis and Management, 4(3), 476. https://doi.org/10.2307/3324261

Verma, S. (2017). The Relantionship Between Emotional Intelligence and Various Psychological Quotients. IOSR Journal of Business and Management, 19(01), 14-18. https://doi.org/10.9790/487x-1901021418

Villagonzalo, R. R. (2016). Intelligence Quotient, Spiritual Quotient, and Adersity Quotient and Academic Performance of Students (St. Alexius College). https://doi.org/10.1017/CBO9781107415324.004

Wardana, A. A. G. A. W., \& Mimba, N. P. S. H. (2016). Pengaruh Kecerdasan Intelektual, Kecerdasan Emosional, Kecerdasan Spiritual, Dan Gender Pada Sikap Etis Mahasiswa Magister Akuntansi Universitas Udayana. EJournal Akuntansi Universitas Udayana, 5(10), 3501-3530. https://doi.org/ISSN: 2337-3067 
Wardani, N. W. R., \& Ratnadi, N. M. D. (2017). Pengaruh Kecerdasan Emosional, Kecerdasan Intelektual, Dan Perilaku Belajar Pada Tingkat Pemahaman Akuntansi. E-Journal Akuntansi Universitas Udayana, 20(2), 1133-1161.

Wells, P. K. (2017). How well do our introductory accounting text books reflect current accounting practice? Journal of Accounting Education, 42(December 2016), 40-48. https://doi.org/10.1016/j.jaccedu.2017.12003

Widyawati, P. G., Immanuela, I., \& Handayani, D. (2014). Pengaruh Kecerdasan Emosional, Perilaku Belajar dan Budaya terhadap Tingkat Pe mahaman Akuntansi dengan Kepercayaan Diri sebagai Variabel Moderating (Studi Empiris pada Mahasiswa di Perguruan Tinggi Swasta Kota Madiun). JRMA | Jurnal Riset Manajemen Dan Akuntansi, 2(1), 25-34.

Yamin, S., \& Kurniawan, H. (2014). SPSS Complete: Teknik Analisis Terlengkap dengan Software SPSS (Edisi 2). Jagakarsa, Jakarta Selatan: Salemba Infotek.

Yin, H. (2015). The effect of teachers emotional labour on teaching satisfaction: Moderation of emotional intelligence. Teachers and Teaching: Theory and Practice, 21(7), 789-810. https://doi.org/10.1080/13540602.2014.995482

Yulianti, P., \& Fitri, M. E. Y. (2017). Evaluasi Prestasi Belajar Mahasiswa Terhadap Perilaku Belajar Dan Motivasi Belajar Mahasiswa Di Perguruan Tinggi Kota Padang Provinsi Sumatera Barat. Jurnal Akuntansi, Ekonomi Dan Manajemen Bisnis, 5(2), 242-251. https://doi.org/10.30871/jaemb.v5i2.575 